\title{
Study of Hepatitis C Virus Infection at a Tertiary Hospital: Genotyping, Risk Factors and Comorbidities
}

\author{
AR Siti Nurul Fazlin, ${ }^{\mathrm{a}} \mathrm{H}$ Hairul Aini, ${ }^{\mathrm{a}} \mathrm{HM}$ Hadzri, ${ }^{\mathrm{b}} \mathrm{MM}$ Mohammed Imad ${ }^{\mathrm{a}}$ \\ ${ }^{a}$ Department of Basic Medical Science, International Islamic University Malaysia, Jalan Sultan Haji Ahmad \\ Shah, Bandar Indera Mahkota, Kuantan, Pahang. \\ ${ }^{b}$ Department of Internal Medicine, International Islamic University Malaysia, Jalan Istana, Bandar Indera \\ Mahkota, Kuantan, Pahang.
}

\begin{abstract}
Introduction: Hepatitis $\mathrm{C}$ virus $(\mathrm{HCV})$ genotyping is very important for the clinical management of HCVinfected patients. The aim of this study was to determine the genotypes of HCV-infected patients and to identify their risk factors and comorbidities. Materials and Methods: This was an observational, cross sectional study in which forty (40) HCV-infected patients attending Gastroenterology Clinic, Hospital Tengku Ampuan Afzan (HTAA) Kuantan Pahang were recruited for the study, from January to July 2014. Nucleotide sequence analysis of the 5'UTR and NS5B region were performed to identify the viral genotypes. Results: Of the 40 samples, $31(77.5 \%)$ isolates were successfully classified into their genotypes and subtypes; $3 a$ (57.5\%), 1a (12.5\%), 3b (2.5\%) and 1b (2.5\%). No genotype 2, 4, 5 and 6 were found in this study. However, there was one mixed-genotype (3a/1a) HCV infection. Risk factors and co-morbidities found in this study include IVDUs, haemodialysis, blood transfusion, surgery and co-infection with HIV. Conclusion: Genotype 3 followed by genotype 1 were the common HCV genotypes found in this study population. Furthermore, the highest risk factors and co-morbidities were IVDUs and co-infection with HIV.
\end{abstract}

KEYWORDS: Hepatitis C, HCV, Genotyping, RT-PCR

\section{INTRODUCTION}

Hepatitis $\mathrm{C}$ has been a major health concern for the past few years. According to the World Health Organization (WHO), approximately 150 million people are chronically infected with $\mathrm{HCV}$, with more than 350,000 die every year. ${ }^{1}$ In Malaysia, the prevalence of hepatitis $C$ is about $1.5 \%$ of total population (30 million), which equal to 450,000 Malaysians. ${ }^{2}$

Hepatitis C virus is small (about $10 \mathrm{~kb}$ in size), positive sense single stranded RNA virus in Flaviviridae family. Different HCV isolates from all over the world show variability in substantial nucleotide sequence throughout the viral genome. Based on these differences, HCV has been categorized into six major genotypes. In addition, HCV genotypes differ from each other by $31-33 \%$ at the nucleotide level. The occurrence of HCV genotypes tends to vary with geographic region. For

Corresponding Author:

Siti Nurul Fazlin Abdul Rahman,

Department of Basic Medical Science, International Islamic University Malaysia,

Jalan Sultan Haji Ahmad Shah,

Bandar Indera Mahkota,

25200 Kuantan, Pahang.

$(\mathrm{H} / \mathrm{P}):+60179306178$

E-mail: fazlin89@yahoo.com instance, genotype 1,2 and 3 are distributed globally while genotype 4,5 , and 6 are very common in geographic areas where chronic hepatitis $C$ is highly prevalent. Meanwhile, in Malaysia, the predominant ones are genotype 3 followed by genotype $1 .^{3,4}$

The genotype of HCV strain is clinically important in determining the severity and aggressiveness of liver infection, as well as patient's response to pegylated interferon and ribavirin therapy and the required duration of such therapy. However, the treatment of choice at the moment has shifted to newer antiviral drugs. In the year of 2011, new drugs were approved by the US Food and Drug Administration (FDA) called Direct Acting Antiviral (DAA) agents that are more effective (> 90\% cure rates), safer and requiring shorter duration of therapy (usually 12 weeks) but they are costlier than the former treatments. So far, these drugs have been found to be effective against almost all HCV genotypes..$^{5-8}$

Although the efficacy of treatment regimens for chronic hepatitis $C$ with the newer generations of DAA drugs has improved and has decreased the clinical importance of viral and host factors that may interfere with the chances of obtaining a sustained viral response (SVR), but the predictive value of viral genotyping ( 3 and $1 \mathrm{a}$ ) and viral kinetics to SVR has not yet been nullified. ${ }^{9}$ Because of this, HCV genotyping is still a useful method not only to predict and monitor the response to therapy 
but also to determine the source of transmission in infected population, to assess risk of disease development, and to determine the prognosis of disease. ${ }^{10}$

$\mathrm{HCV}$ is a blood-borne virus where infected patients usually acquire the infection through injection drug use, blood transfusion, or organ transplant. In the case of tattooing, body piercing and acupuncture, inadequate sterilization can lead to transmission of the virus. ${ }^{11-12}$ Once infected, patient may become either asymptomatic or symptomatic. In symptomatic patients, virus replicates aggressively in the hepatocytes, thus disease manifestation including fever, malaise, and jaundice. Besides that, the symptom on HCV-infected patients can be worsened by a comorbid condition, where another disease or disorder co-exists with hepatitis C infection. The condition may interfere with the outcome and effectiveness of the treatment. Common comorbidities for hepatitis $\mathrm{C}$ disease include HIV co-infection, kidney disease, autoimmune disease for example rheumatoid arthritis, alcohol abuse and others. ${ }^{13}$

The main aim of this study was to determine the $\mathrm{HCV}$ genotypes via nucleic acid sequencing and phylogenetic analysis among HCV patients at Hospital Tengku Ampuan Afzan (HTAA), Kuantan, Pahang. In addition, associated risk factors and comorbidities were also assessed during sample collection.

\section{MATERIALS AND METHODS}

Ethical approval was obtained from Medical Research Ethic Committee (MREC) and Clinical Research Centre (CRC), HTAA. The application was made through National Medical Research Register (NMRR) website (www.nmrr.gov.my).

\section{Study Population}

The study was an observational and cross-sectional study. It was conducted with samples obtained from patients attending Medical Outpatient Gastroenterology Department, HTAA from January to July 2014. HTAA is tertiary referral hospital with 800 beds, which received patients from East Coast region of Pahang and southern region of Terengganu. A total of 40 samples were sent to the laboratory of the Basic Medical Sciences Department, Kulliyyah of Medicine, IIUM, for HCV RNA detection and characterization.

\section{Patient's recruitment \& Interview}

Patients were recruited after they had been confirmed to be positive for anti-HCV antibodies during screening. The patient's informed consent form was obtained prior to blood collection. Later on, the patient was interviewed using a structured questionnaire (Appendix) covering demographics and risk factors of HCV acquisition. Clinical and other data of each patient were obtained from the hospital file record.

\section{Sample processing}

Blood was drawn and collected in collection tubes. Within 6 hour of blood being drawn, the tubes were centrifuged at 3,500 rpm for 15 minutes at room temperature. After centrifugation, serum samples were aliquoted and stored in $-70^{\circ} \mathrm{C}$ until further used. Each sample was labeled with number, name and date.

\section{Nucleic Acid Extraction and RT-PCR}

HCV RNA was extracted from $200 \mu$ serum sample using QIAamp High Pure Viral RNA Extraction kit (Qiagen, Germany). Reverse Transcription Polymerase Chain Reaction (RT-PCR) was performed, in which HCV RNA was reverse transcribed into complementary DNA (cDNA) first and later, the target 5'UTR and NS5B regions were amplified. In this study, these following primers were used for RT-PCR reaction: i) HCV-F (forward; 5' AGT GTT GTG CAG CCT CCA G 3') and HCV-R (reverse; 5' ACT GCC TGA TAG GGT GCT TG 3') primers for 5'UTR based assays, generating a $212 \mathrm{bp}$ amplicon. ii) Samples with negative outcome were tested again using semi-nested RT-PCR. The HCV-R primer was replaced with $\mathrm{nR}-\mathrm{HCV}$ (reverse; 5' CGG TGA GTA CAC CGG AAT TG 3') primer generating a 153 bp amplicon. iii) For NS5B-based assays, the region was amplified using 243-F (forward; 5' TGG GGA TCC CGT ATG ATA CCC GCT GCT TTG A 3') and 242-R (reverse; 5' GGC GGA ATT CCT GGT CAT AGC CTC (GT GAA 3') primers universal to genotype 1 until 5 , adopted from previous study ${ }^{13}$ generating a 400 bp amplicon. iv) Meanwhile, for genotype 6, another set of primers were used which are 7946-F (forward; 5'TTA ACC ACA TCA ACT CCG TG 3') and 8643R (reverse; 5'CCG AAT ACC TGG TCA TAG C 3') generating $695 \mathrm{bp}$ amplicon. The thermal profile for the amplification of both regions was as follows; initial denaturation at $94^{\circ} \mathrm{C}$ for 3 minutes; 35 cycles with denaturation at $94^{\circ} \mathrm{C}$ for 1 minute, annealing at $56^{\circ} \mathrm{C}$ for 1 minute and elongation at $72^{\circ} \mathrm{C}$ for 3 minutes. The reaction was terminated with a final extension at $72^{\circ} \mathrm{C}$ for 5 minutes. The RT-PCR reaction was carried out in Automated Gene Amp PCR System $9700 \circledR$ (Applied Bio systems, USA).

\section{Detection of PCR product}

A $25 \mu$ l of the PCR product was mixed with $5 \mu l$ of loading dye and subsequently electrophoresed on a $1.5 \%$ agarose gel (Peqlab, Germany) in 10x TAE buffer (Life Technologies, USA) at 100 volt for 45 minutes. The gel was stained with intercalating agent, ethidium bromide which acts as nucleic acid stain for DNA visualization. 100 bp DNA ladder and 6x DNA loading dye (Thermoscientific, USA) were used to identify the specified amplified fragment. A specific amplified band was then visualized under ultraviolet light. 


\section{Sequencing}

Amplicons purification were done using MinElute gel extraction kit (Qiagen,Valencia, CA, USA). The purified PCR products were then sequenced using the same primers used in PCR. Each of the products was sequenced twice from both directions on $A B I$ 3730XL DNA Analyser (Applied Bio system, USA).

\section{Sequence alignment}

Bioedit 7.2.5 software (www.bioedit.com) was used to analyse and align the sequencing results together with the reference sequences obtained from National Centre for Biotechnology Information (NCBI) homepage.

\section{Phylogenetic analysis}

The phylogenetic trees were constructed utilizing Mega 6.0 (www.megasoftware.net) software to characterize HCV isolates into different genotypes and subtypes, using the neighbour-joining method and Jukes-Cantor model on the aligned sequences. .

\section{RESULTS}

A total of 40 seropositive samples were analysed using both 5'UTR and NS5B-based assays. In the RTPCR targeting 5'UTR, all samples (100\%) were tested positive for HCV RNA. Most of the HCV RNA was detectable in the first round RT-PCR. However, there was 1 sample that was detectable only by semi nested RT-PCR. Meanwhile, viral genome amplifications using NS5B-based assay were successful in 31 out of 40 samples (77.5\%).
Non-amplified samples were then tested in RT-PCR using a set of primers specific for genotype 6 but the amplification was also unsuccessful.

\section{Phylogenetic analysis}

All HCV isolates with positive amplification from the first round RT-PCR were subjected to direct sequencing for phylogenetic analysis (Figure 1), in order to determine their genotype. Semi-nested RTPCR products were discarded from the analysis due to its sequence sequencing errors.

\section{Genotypes Distribution}

Based on the analysis of both5'UTR and NS5B-based assays (Table I), genotype 3 was observed in 25 out of 31 patients $(25 / 31 ; 80.6 \%)$ with chronic HCV infection. Of these, $24(24 / 31 ; 77.4 \%)$ patients were infected with HCV subtype $3 a$ and one $(1 / 31 ; 3.2 \%)$ patient was infected with HCV subtype $3 \mathrm{~b}$.

On the other hand, HCV genotype 1 was found in 6 patients $(5 / 31 ; 16.15), 5$ of them were infected with subtype $1 \mathrm{a}$ and one patient $(1 / 31 ; 3.2 \%)$ was infected with subtype $1 \mathrm{~b}$. Thus, subtype $3 \mathrm{a}$ was the most prevalent, followed by subtype $1 a, 1 b$ and $3 b$. None of the study isolates were found to be of genotypes 2, 4 and 5 .

However, there was one isolate (PAT 33) with mixed -genotype infection was initially identified as genotype 1a via 5'UTR-based assay and later was identified as genotype $3 a$ by NS5B-based assays (Figure 1).

Table I: Distribution of HCV genotypes and subtypes

\begin{tabular}{|c|c|c|c|c|}
\hline $\begin{array}{c}\text { Genotype } \\
\text { and subtype }\end{array}$ & $\begin{array}{c}\text { 5'UTR-based assays } \\
{[39 / 40](\%)}\end{array}$ & $\begin{array}{c}\text { NS5B-based assays } \\
{[31 / 40](\%)}\end{array}$ & $\begin{array}{c}\text { Mono infection*, } \\
\text { 5'UTR + NS5B } \\
\text { [30/40] (\%) }\end{array}$ & $\begin{array}{c}\text { Mixed-genotype } \\
\text { infection, 5'UTR + } \\
\text { NS5B [1/40] (\%) }\end{array}$ \\
\hline $3 a$ & $28(70)$ & $24(60)$ & $23(57.5)$ & \multirow{2}{*}{$1(\mathrm{G} 1+\mathrm{G} 3)(2.5)$} \\
\hline $1 a$ & $9(22.5)$ & $5(12.5)$ & $5(12.5)$ & \\
\hline $1 b$ & $1(2.5)$ & $1(2.5)$ & $1(2.5)$ & - \\
\hline $3 b$ & $1(2.5)$ & $1(2.5)$ & $1(2.5)$ & - \\
\hline
\end{tabular}

Note: G1= Genotype 1, G3= Genotype 3

* Mono infection refers to concordant HCV genotyping results based on both 5'UTR and NS5B-RT-PCR assays. 
A

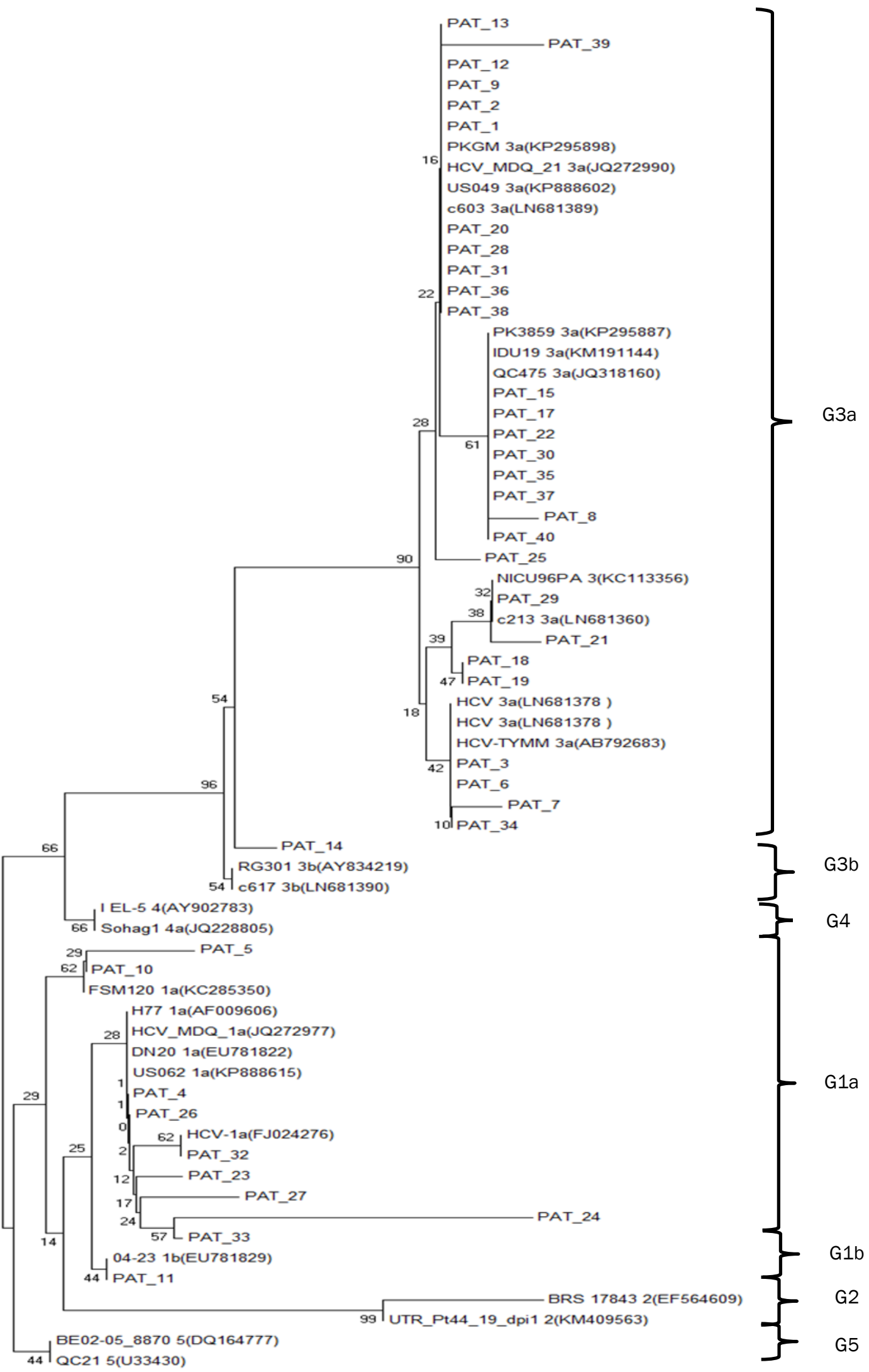

$$
\stackrel{\longmapsto}{0.01}
$$




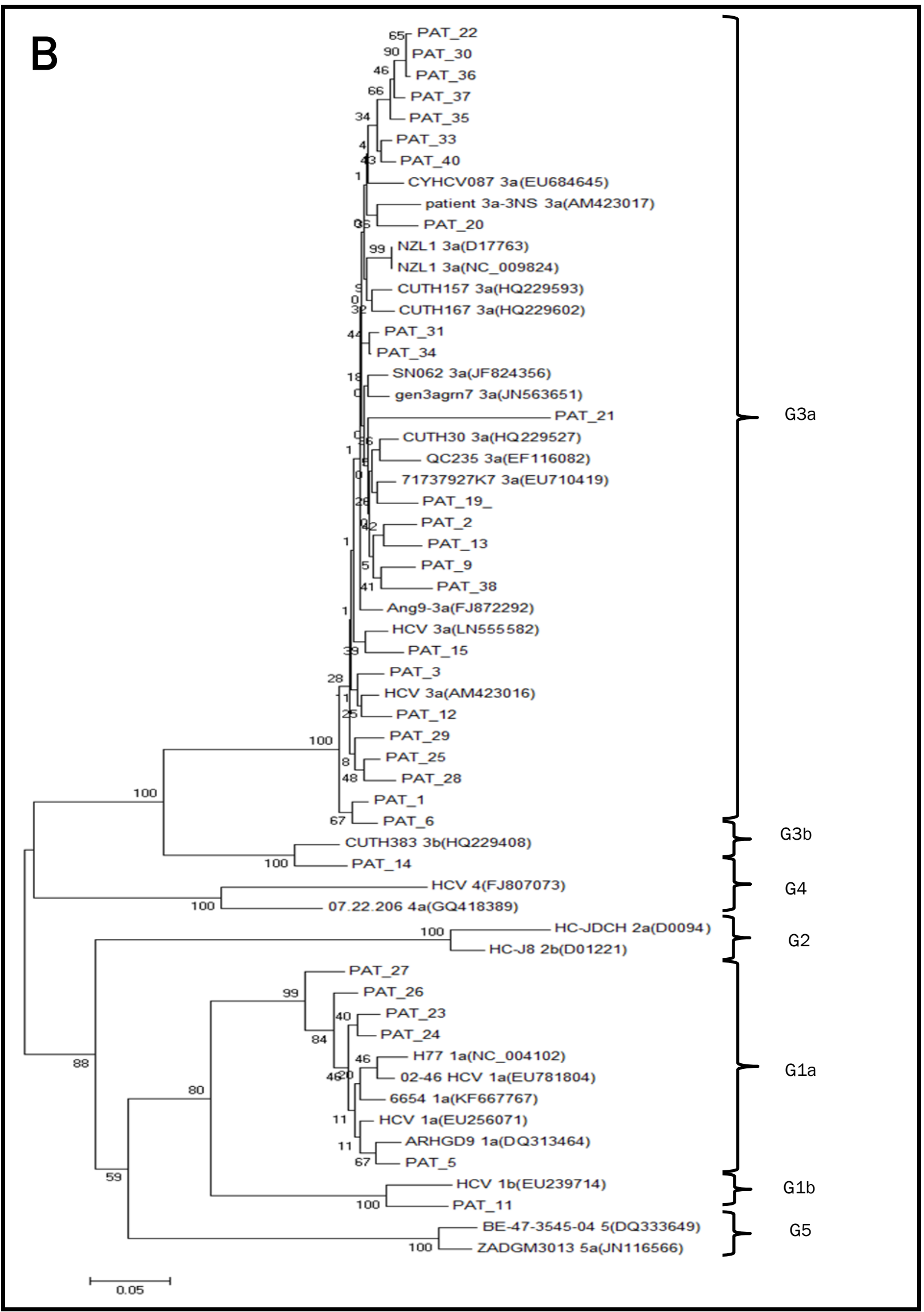

Figure 1: Phylogenetic analysis of study isolates from HCV-infected patients at HTAA, Kuantan. Study isolates were labeled as PAT followed by numeric digit. Reference sequences were labeled with name and NCBI accession number. The percentage of replicate trees in which the associated taxa clustered together in the bootstrap test (1000 replicates) is shown next to the branches. The tree is drawn to scale, with branch lengths in the same units as those of the evolutionary distances used to infer the phylogenetic tree. The evolutionary distances were computed using the JukesCantor method and are in the units of the number of base substitutions per site. (A) Genotypes classification based on 5'UTR PCR products sequences. (B) Genotypes classification based on NS5B PCR products sequences. G = genotype. 
Analysis of genotype distribution based on age, gender and race, showed that below the age of 45 years, males of Malay ethnicity were predominant in this study (Table II). Besides that, the route of HCV transmission (Table III) included intravenous drug use (IVDU), blood transfusion, surgery and haemodialysis. Most of the study patients (42\%) denied any high-risk activity such as history of injecting-drug use and so on. But, 7 patients $(22.6 \%)$ infected with HCV genotype 3 and 3 others $(9.7 \%)$ with genotype 1 were ex-IVDUs. Meanwhile, 4 patients $(13 \%)$ were infected with HCV genotype 3 during blood transfusion. Haemodialysis is the third common route of HCV acquisition with 2 patients (6.5\%) being infected with genotype 3 and 1 (3.2\%) with genotype 1 . Besides that, 1 patient (3.2\%) acquired the infection with genotype 3 during surgery.

Table II: Association of HCV genotypes with demographic factors

\begin{tabular}{|c|c|c|c|c|c|c|}
\hline Parameter & $\begin{array}{c}\text { Genotype } 3 \\
(n=24)(\%)\end{array}$ & $\begin{array}{c}\text { Genotype } 1 \\
(n=6)(\%)\end{array}$ & $\begin{array}{c}\text { Mixed-genotype } \\
(1 \mathrm{a} / 3 \mathrm{a})(\mathrm{n}=1) \\
(\%)\end{array}$ & Total (\%) & $\mathrm{X}^{2}$ & P-value \\
\hline \multicolumn{7}{|l|}{ Gender } \\
\hline $\begin{array}{c}\text { Male } \\
\text { Female }\end{array}$ & $\begin{array}{c}21(67.7) \\
3(9.7)\end{array}$ & $\begin{array}{l}3(9.7) \\
3(9.7)\end{array}$ & $\begin{array}{c}1(3.2) \\
-\end{array}$ & $\begin{array}{c}25(80.6) \\
6(19.4)\end{array}$ & 4.573 & 0.1016 \\
\hline \multicolumn{7}{|l|}{ Race } \\
\hline $\begin{array}{l}\text { Malay } \\
\text { Chinese } \\
\text { Indian }\end{array}$ & $\begin{aligned} 19 & (61.3) \\
3 & (9.7) \\
2 & (6.5)\end{aligned}$ & $\begin{array}{c}5(16.1) \\
1(3.2) \\
-\end{array}$ & $\begin{array}{c}1(3.2) \\
- \\
-\end{array}$ & $\begin{array}{c}25(80.6) \\
4(12.9) \\
2(6.5)\end{array}$ & 0.8396 & 0.9331 \\
\hline \multicolumn{7}{|l|}{ Age } \\
\hline $\begin{array}{l}<45 \\
>45\end{array}$ & $\begin{array}{c}16(51.6) \\
8(25.8)\end{array}$ & $\begin{array}{c}5(16.1) \\
1(3.2)\end{array}$ & $1(3.2)$ & $\begin{array}{ll}21 & (67.7) \\
10 & (32.3)\end{array}$ & 4.573 & 0.1016 \\
\hline
\end{tabular}

Table III: Association of HCV genotypes with risk factors, co-infection and alcohol consumption

\begin{tabular}{|c|c|c|c|c|c|c|}
\hline Parameter & $\begin{array}{l}\text { Genotype } 3 \\
\text { [24/31] (\%) }\end{array}$ & $\begin{array}{c}\text { Genotype } 1 \\
\text { [6/31] (\%) }\end{array}$ & $\begin{array}{c}\text { Mixed-genotype } \\
(\mathrm{G} 1+\mathrm{G} 3)[1 / 31] \\
(\%)\end{array}$ & Total (\%) & $\mathrm{X}^{2}$ & P-value \\
\hline \multicolumn{7}{|l|}{ Risk factors } \\
\hline $\begin{array}{l}\text { IVDU } \\
\text { History of } \\
\text { blood } \\
\text { transfusion } \\
\text { Surgery } \\
\text { Hemodialysis } \\
\text { Unknown }\end{array}$ & $\begin{aligned} 1 & (3.2) \\
2 & (6.5) \\
10 & (32.3)\end{aligned}$ & $\begin{array}{l}1(3.2) \\
2(6.5)\end{array}$ & $\begin{array}{c}- \\
- \\
1(3.2)\end{array}$ & $\begin{array}{c}10(32.3) \\
4(13) \\
\\
1(3.2) \\
3(9.7) \\
13(42)\end{array}$ & 3.792 & 0.8754 \\
\hline \multicolumn{7}{|c|}{ Co-Infection with HIV } \\
\hline $\begin{array}{l}\text { Yes } \\
\text { No }\end{array}$ & $\begin{array}{l}3(9.7) \\
21(70)\end{array}$ & $\begin{array}{l}2(6.5) \\
4(13)\end{array}$ & $1(3.2)$ & $\begin{array}{c}5(16.1) \\
26(83.4)\end{array}$ & 1.739 & 0.4192 \\
\hline \multicolumn{7}{|c|}{ Other (Alcohol consumption) } \\
\hline $\begin{array}{l}\text { Yes } \\
\text { No }\end{array}$ & $\begin{array}{c}5(16.1) \\
19(61.3)\end{array}$ & $\begin{array}{c}1(3.2) \\
5(16.1)\end{array}$ & $1(3.2)$ & $\begin{array}{c}6(19.4) \\
25(80.6)\end{array}$ & 0.3014 & 0.8601 \\
\hline
\end{tabular}




\section{DISCUSSION AND CONCLUSION}

$\mathrm{HCV}$ genotypes 1 and 3 are the most common genotypes found globally. In Malaysia, these two genotypes are frequently encountered circulating among HCV-infected patients. ${ }^{3,4,12}$ Similarly, in this study, both of these HCV genotypes were detected (Table I) using 5'UTR and NS5B-based assays. Using NS5B-based assay as the reference method, 5'UTRbased assay correctly identified a total of 30 positive samples as mono-type HCV infections with genotypes $1 \mathrm{a}, 1 \mathrm{~b}, 3 \mathrm{a}$ and $3 \mathrm{~b}$. However, there was one patient (PAT 33) with mixed HCV-genotypes infection.

According to Hamzah et al.,(2012), this case of mixed infection had resulted from repeated blood transfusions among HCV chronically infected patients undergoing haemodialysis. Other than that, infection by more than one genotype is possibly related to a decline in immune function and exposure to a new viral variant. ${ }^{13}$ The clinical repercussion of this mixed infection is that it might worsen liver damage and accelerate the progression of liver disease. ${ }^{14-15}$ This particular patient denied any high risk behaviour during questionnaire session.

Genotyping of HCV plays a role in predicting disease outcome, progression of the disease as well as the response to antiviral therapy. HCV infection usually resolves naturally in some patients but the majority of them (about 80\%) enter the chronic phase where $\mathrm{HCV}$ is detectable in their blood at least six months after initial exposure. ${ }^{16}$ The response to pegylated interferon and ribavirin therapy of HCV genotype 1 is the slowest compared to other genotypes.

Typically, 24 weeks is the standard duration for antiviral therapy of genotype 2 or 3 but for genotype 1,48 weeks are required to complete the therapy ${ }^{17}$. In this study, 24 patients were infected with HCV genotype 3 and 6 other patients were infected with HCV genotype 1 . This indicates that compared to other HCV infected patients, the six patients with genotype 1 need a longer treatment duration and more care in their management. Although the response to DAA therapy and the achievement of sustained viral response is less affected by HCV viral genotypes and subtypes as compared to the previous mode of antiviral therapy, yet particular HCV genotypes and subtypes may still influence the response to some of this newer antiviral agents. ${ }^{18,19}$

Intravenous drug use (IVDU) is the common risk factor observed in this study for both HCV genotype 1 and 3 . This is consistent with the result of previous studies reporting that IVDU was the primary route of HCV transmission in Malaysia., ${ }^{3,420-22}$ Besides that, IVDU also the major risk factor in other countries. ${ }^{23-25}$ The act of sharing needles, syringes and/or paraphernalia among IVDUs can lead to the widespread of HCV infection.
Another route of $\mathrm{HCV}$ transmission is through blood transfusion but that was before introduction of blood screening when it was the leading cause of HCV infection. However, in 1992, a series of effective screening tests were introduced and since then, the number of people acquiring HCV infection through that route has dwindled rapidly. In this study, blood transfusion was the second route of HCV acquisition after IVDU, followed by haemodialysis and surgery. All four patients (13\%) who had received blood transfusion were infected with HCV genotype 3 and possibly received transfusions prior to 1990. Similar trend was observed by Mohamed et al.,(2013) who also found that HCV genotype 3 infected most of the study patients. $^{3}$

Co-infection is a condition where an individual is infected with more than one pathogen. In such cases, HCV infected patients may frequently be exposed to other viral infections such as HIV and HBV via IVDU or multiple transfusions. About $16 \%$ of the study population were co-infected with HIV which actually accelerates liver disease progression and cause high morbidity and mortality as compared to mono HCV infection. ${ }^{23}$ Other than that, information regarding alcohol consumption was also obtained. Alcohol consumption is an important cofactor in HCV infection but the exact mechanism by which alcohol plays a role in worsening HCV infection, besides liver injury, is still unknown. ${ }^{26-27}$ In this study, about $20 \%$ of the study patients consumed alcohol and this finding could be of help in predicting the severity of the liver injury as well as monitoring the progression of the disease.

In conclusion, genotype 3 was the major genotype found among $\mathrm{HCV}$-infected patients in HTAA followed by genotype 1 . Genotypes 2, 4, 5 and 6 were not detected throughout this study. This finding is vital for the clinical management of HCVinfected patients since genotype 3 gives a better response towards the treatment; hence the treatment duration is shorter as compared to genotype 1 . Besides that, the main risk factors and co-morbidities found in this study were IVDUs and HIV co-infection. These findings are also beneficial for future epidemiological studies on HCV genotypes prevalence, transmission and predicting sustained viral response to antiviral therapy in Pahang.

\section{Limitation}

There were few studies done before to ascertain the relation between HCV genotypes prevalence and risk factors. Based on their finding, intravenous drug use was the main source of infection for HCV infected patients with genotype 1 or $3 ., 28$ However, such association cannot be established in our study since the sample size was small. Therefore, more studies with larger sample size are required in order to study the HCV infection patterns, especially in the context of controlling morbidity and mortality rate caused by liver disease. 


\section{CONFLICT OF INTEREST}

The author declares that there is no conflict of interests regarding the publication of this paper.

\section{ACKNOWLEDGEMENT}

The authors acknowledge the Ministry of Higher Education Malaysia for funding this work through Research Acculturation Grant Scheme (RAGS14-048-0111) and the State Department of Ministry of Health for study consent and special thanks to all nurses in Gastroenterology Clinic, HTAA for their valuable help in performing this study.

\section{REFERENCES}

1. World Health Organisation. Hepatitis C. 2002. p. 1-69. Retrived from: http://www.who.int/ Csr/Disease/Hepatitis/Whocdscsrlyo2003/En/ Index4.Html

2. Lavanchy D. Evolving epidemiology of hepatitis $C$ virus. Clin Microbiol Infect. European Society of Clinical Infectious Diseases 2011; 17:107-15.

3. Mohamed N, Rashid ZZ, Wong KK, Abdullah S

a., Rahman MM. Hepatitis $C$ genotype and associated risks factors of patients at University Kebangsaan Malaysia Medical Centre. Pakistan J Med Sci 2013; 29:1-5.

4. Ho S-H, Ng K-P, Kaur H, Goh K-L. Genotype 3 is the predominant hepatitis $C$ genotype in a multi-ethnic Asian population in Malaysia. Hepatobiliary Pancreat Dis Int 2015; 14:281-6.

5. Amario DD, Sanada F, Zheng H, Ogórek B, D P, Rondon-clavo C, et al. Boceprevir for Untreated Chronic HCV Genotype 1 Infection. N Engl J Med 2011; 1795-806.

6. Sherman KE, Flamm SL, Afdhal NH, Nelson DR, Sulkowski MS, Everson GT, et al. Responseguided telaprevir combination treatment for hepatitis C virus infection. N Engl J Med 2011; 365:1014-24.

7. Bacon BR, Gordon SC, Lawitz E. Boceprevir for Previously Treated Chronic HCV Genotype 1 Infection. N Engl J Med 2011.

8. Elbaz T, El-Kassas M, Esmat G. New era for management of chronic hepatitis $C$ virus using direct antiviral agents: A review. J Adv Res 2015; 6:301-10.

9. Cavalcante LN, Lyra AC. Predictive factors associated with hepatitis $C$ antiviral therapy response. World J Hepatol 2015; 7:1617-31.

10. Yin W, Huang C, Qiu F, Liu L, Wang F, Zhou J, et al. Risk factors of hepatitis $C$ virus transmission and genotype distribution in former blood donors from Chinese rural area. BMC Public Health. England 2015; 15:184.

11. Vukovic VR, Baskic D, Mijailovic Z, Djurdjevic $\mathrm{P}$, Jovanovic D, Mitrovkic S, et al. Association between risk factors, basal viral load, virus genotype and the degree of liver fibrosis with the response to the therapy in patients with chronic hepatitis $C$ virus infection. Vojnosanit Pregl Serbia 2015; 72:505-9.
12. Wasitthankasem R, Vongpunsawad S, Siripon N, Suya C, Chulothok P, Chaiear K, et al. Genotypic Distribution of Hepatitis C Virus in Thailand and Southeast Asia. PLoS One 2015; 10:e0126764.

13. Hamzah HA, Mustafa MI, Seman MR, Abdullah N. Mixed-genotypes Infections with Hepatitis C Virus in Hemodialysis Subjects. Med J Malaysia 2012; 67:199-203.

14. Baré $P$, Bianco RP. Mixed Genotypes in Hepatitis C Virus Infection. In: Batorova A, editor. Hemophilia. 2012. p. 99-110.

15. Chen YD, Liu MY, Yu WL, Li JQ, Dai Q, Zhou $Z Q$, et al. Mix-infections with different genotypes of HCV and with HCV plus other hepatitis viruses in patients with hepatitis $C$ in China. World J Gastroenterol 2003; 9:984-92.

16. Ishii S, Koziel MJ. Immune responses during acute and chronic infection with hepatitis $C$ virus. Clin Immunol 2008; 128:133-47.

17. Ghany MG, Strader DB, Thomas DL, Seeff LB. Diagnosis, management, and treatment of hepatitis C: An update. Hepatology 2009; 49:1335-74.

18. Nezam A, Stefan Z, Paul K, Mario C, Norman G Massimo $P$, et al. Ledipasvir and Sofosbuvir for Untreated HCV Genotype 1 Infection. N Engl J Med 2014; 370:1889-98.

19. Stefan Z, M. DG, Riina S, Alessandra M, Robert $\mathrm{F}, \mathrm{H}$. HR, et al. Sofosbuvir and Ribavirin in HCV Genotypes 2 and 3. N Engl J Med 2014; 370:1993-2001.

20. Duraisamy G, Zuridah H, Ariffin MY. Prevalence of hepatitis $C$ virus antibodies in blood donors in Malaysia. Med J Malaysia 1993; 48:313-6.

21. Sinniah M. Review of hepatitis $C$ in Malaysia. Med J Malaysia 1992; 47:155-7.

22. Ng KP, Saw TL, Wong NWD, Goh KL, Chuah SY, Nagaratnam M. The Prevalence of Anti-HCV Antibody in Risk Groups and Blood donors. Med J Malaysia 1995; 50:302-5.

23. Sy $T$, Jamal MM. Epidemiology of hepatitis $C$ virus (HCV) infection. Int J Med Sci 2006; 3:416.

24. Shepard CW, Finelli L, Alter MJ. Global epidemiology of hepatitis $C$ virus infection. Lancet Infect Dis 2015; 5:558-67.

25. Murphy EL, Bryzman SM, Glynn SA, Ameti DI, Thomson RA, Williams AE, et al. Risk factors for hepatitis $C$ virus infection in United States blood donors. Hepatology 2000; 31:756-62.

26. McCartney EM, Semendric L, Helbig KJ, Hinze $\mathrm{S}$, Jones $\mathrm{B}$, Weinman $\mathrm{S}$ a, et al. Alcohol metabolism increases the replication of hepatitis $C$ virus and attenuates the antiviral action of interferon. J Infect Dis 2008; 198:1766-75.

27. Safdar K, Schiff ER. Alcohol and hepatitis C. Semin Liver Dis 2004; 24:305-315.

28. Garcia-Montalvo BM, Galguera-Colorado PL. Distribution of hepatitis $C$ virus genotypes, risk factors and liver disease in patients from Yucatan, Mexico. Ann Hepatol 2008; 7:345-9. 
APPENDIX

\section{QUESTIONNAIRE}

\section{Infection History}

1. Do you know that you have been infected with HCV?

2. Do you know that hepatitis $C$ can be transmitted through blood?

3. Do you have any idea on how you have been infected with HCV?

If yes, how?

4. Do you have any family member with HCV?

If yes, what is the relationship?

5. Do you drink alcohol?

6. Do you have any history of intravenous drug use (IVDU)?

7. Do you undergo hemodialysis treatment?

8. Do you have any history of blood transfusion?

If yes, when did the first time the first time you receive the blood?

9. Why did you receive the blood transfusion?

\begin{tabular}{|l|l|}
\hline & Accident/Trauma \\
\hline & Surgery \\
\hline & Anemia/thrombocytopenia \\
\hline & $\begin{array}{l}\text { Blood disease (Hemophilia/Sickle-cell } \\
\text { disease) }\end{array}$ \\
\hline
\end{tabular}

10. Do you have any history of surgery? YES/NO

When did you undergo for that surgery?

11. Do you have any history of tissue or organ transplant?

YES/NO

What kind of tissue or organ?

When did you have the tissue or organ transplant?
YES/NO

YES/NO

YES/NO

12. Did you share any personal items (for example: tooth brush, razor, and nail cutter) with other people?

13. Are you on antiviral therapy?

YES/NO

\begin{tabular}{|l|l|l|l|}
\hline & Pegasys & & Intron A \\
\hline & Copegus & & Roferon A \\
\hline & Peg-intron & & Ribavirin \\
\hline & Rebetol & & $\begin{array}{l}\text { Others (please } \\
\text { specify }\end{array}$ \\
\hline
\end{tabular}

14. Other information:

YES/NO

YES/NO

*Notes: commercial names for antiviral drug that have been approved by Food and Drug

Administration (FDA) for HCV

Pegasys (peginterferon alfa-2a)

Copegus (ribavirin)

Peg-Intron (peginterferon alfa-2a)

Rebetol (ribavirin)

Intron A (peginterferon alfa-2a)

Roferon A (peginterferon alfa-2a) 
